\title{
Pengaruh Kualitas Produk, Harga, Promosi dan Pelayanan Terhadap Kepuasan Konsumen serta Dampaknya Pada Keputusan Pembelian
}

STUDI PADA KONSUMEN ALAT MESIN PENGOLAH KOPI DI PT. KARYA MITRA USAHA

Customer

Satisfaction and

Marketing Mix

\author{
Budiman Marpaung ${ }^{1}$ dan Ani Mekaniwati ${ }^{2}$ \\ Program Studi Manajemen, Fakultas Bisnis IBI Kesatuan \\ E-Mail: 'budiman.marpaung@stiekesatuan.ac.id, ${ }^{2}$ a.meka@ibik.ac.id
}

Submitted: APRIL 2020

\section{ABSTRACT}

This research aims to : a) determine the direct and simultaneous influence of production quality, price, promotion and service quality on customer satisfaction, b). kow the direct and simultaneous influence of production quality, price, promotion, service quality and customer satisfaction on purchasing decicions, c). determine the indirect and total impact on purchasing decicions through interventing variable customer satisfaction. The study was conducted on consumers of coffee processing machines. Respondents were determined by purposive sampling and accidental sampling. The numbers of respondents 79 people. The analysis method used is multiple linier regression with path analysis. The results showed : a) production quality and promotional activities have a direct and significant effect on positive direction on consumer satisfaction and purchasing decicions, while the quality of service the direct is not significant, but with a positive direction on customer satisfaction and buying decicions. b) price have a direct and significant effect with a negative direction on contumer satisfaction and consumer purchasing decicions, c) consumer satisfaction has a direct and significant effect on the positive direction of purchasing decicions, d) production quality, price, promotional activities and service quality simultaneously have a significant effect on contumer satisfaction, e) production quality, price, promotional activities, service quality and customer satisfaction simultaneously have a significant effect on purchasing decicions, f). consumer satisfaction as an interventing variable has an impact on increasing the total coefficient through increasing the indirect coefficient

Keywords : production quality, price, promotion service, satisfaction, purchase decicions

\begin{abstract}
ABSTRAK
Penelitian ini bertujuan untuk : a) mengetahui pengaruh langsung dan simultan kualitas produksi, harga, promosi dan kualitas pelayanan terhadap kepuasan konsumen, b) mengetahui pengaruh langsung dan simultan kualitas produksi, harga, promosi, kualitas pelayanan dan kepuasan konsumen terhadap keputusan pembelian, c). menentukan dampak tidak langsung dan total terhadap keputusan pembelian melalui variabel interventing kepuasan konsumen. Penelitian dilakukan pada konsumen alat mesin pengolah kopi. Responden ditentukan dengan purposive sampling dan accidental sampling. Jumlah responden 79 orang. Metode analisa digunakan regresi linier berganda dengan analisis lintasan (path analysis). Hasil penelitian menunjukkan: a). Kualitas produksi dan kegiatan promosi berpengaruh langsung dan signifikan dengan arah positip terhadap kepuasan konsumen dan keputusan pembelian. Sedangkan kualitas pelayanan pengaruh langsungnya tidak signifikan, tetapi dengan arah positif terhadap kepuasan konsumen dan keputusan membeli. b). Harga berpengaruh langsung dan signifikan dengan arah negatif terhadap kepuasan konsumen dan
\end{abstract}

\section{JIMKES}

Jurnal Ilmiah Manajemen Kesatuan Vol. 8 No. 1,2020 pp. $29-38$ ISSN $2337-7860$ E-ISSN 2721 - 169X 
Customer

Satisfaction and

Marketing Mix

keputusan pembelian konsumen. c). Kepuasan konsumen berpengaruh langsung dan signifikan dengan arah positif terhadap keputusan pembelian. d). Kualitas produksi, harga, kegiatan promosi dan kualitas pelayanan secara simultan berpengaruh signifikan terhadap kepuasan konsumen e). Kualitas produksi, harga, kegiatan promosi, kualitas pelayanan dan kepuasan konsumen secara simultan berpengaruh signifikan terhadap keputusan pembelian. f). Kepuasan konsumen sebagai variabel interventing berdampak pada peningkatan koefisien total melalui peningkatan koefisien tidak langsung

Kata kunci : kualitas produksi, harga, promosi, pelayanan, kepuasan, keputusan pembelian

\section{PENDAHULUAN}

Konsumsi kopi di Indonesia setiap tahun semakin meningkat, hal ini dapat dilihat dari maraknya bisnis bisnis ini mulai dari yang sederhana, kelas menengah sampai kelas elit, seperi warung kopi, kafe dan starbuck. Seiring dengan peningkatan konsumsi tersebut juga diikuti dengan peningkatan produksi kopi. Selama 5 tahun terakhir (2016 2020) produksi meningkat dengan pertumbuhan 5,31\% pertahun (Dirjen Perkebunan, 2019). Sejalan dengan peningkatan produksi tersebut terjadi juga peningkatan permintaan alat mesin pengolah bahan mentah kopi (biji kipi) menjadi berbagai produk baik setengah jadi maupun produk jadi (finish product). Para pengusaha dibisnis mekanisasi alat-alat mesin pertanian pun semakin banyak masuk bisnis tersebut dan akibatnya persaingan juga semakin ketat dari tahun ke tahun. Kondisi persaingan yang demikian berakibat pada para produsen mesin pengolah kopi, mau tidak mau harus berusaha merebut hati para pembeli. Salah satu upaya memenangkan persaingan adalah mengetahui faktor-faktor apa saja yang dipertimbangkan konsumennya dalam memutuskan pembelian mesin pengolah kopi. Sebagai pengusaha yang berbisnis dalam produk mesin pengolah kopi, tentunya mempertimbangkan berbagai aspek. Salah satu faktor utama dalam merebut pasar yang berkaiatan dengan produksi adalah kualitas (Heizer dan Render, 2015).

Pada umumnya dalam bisnis harga merupakan faktor penting sebelum memutuskan pembelian, peranan harga terutama elastisitasnya erat kaitannya dengan produk barang dan jasa (Soekirno, et all, 2017). Demikian juga halnya dengan kegiatan promosi juga merupakan hal penting diketahui seseorang konsumen sebelum memutuskan pembelian (Kotler dan Keller, 2009). Faktor lainnya yang tidak kalah pentingnya dan mempengaruhi keputusan membeli adalah faktor psikologis, terutama kualitas pelayanan (Engel et all, 1994). Menjadi pertanyaan adalah apakah faktor kualitas produksi, harga, kegiatan promosi dan kualitas pelayanan berpengaruh langsung terhadap keputusan pembelian atau mempengaruhi keputusan membeli melalui variabel antara (interventing) kepuasan konsumen?. Dengan semakin meningkatnya kepuasan konsumen cenderung akan mempengaruhi keputusan pembelian (Engel et all, 1994).

Tujuan penelitian ini adalah untuk menganalisis bagaimana Pengaruh Kualitas Produk, Harga, Promosi Dan Pelayanan Terhadap Kepuasan Konsumen Serta Dampaknya pada Keputusan Pembelian.

Kualitas produksi adalah kemampuan sebuah barang dan jasa untuk memenuhi kebutuhan pelanggan. Pengertian kualitas sangat luas, paling tidak dimensi kualitas terdiri dari performance, features, reliability, conformance, durability, aestehetics, safety dan persepsi (Heizer dan Render, 2015). Kristian dan Widyanti (2016), dalam penelitiannya menggunakan indikator kualitas antara lain kinerja produk, fitur produk, keandalan produk, daya tahan, estetika, brand image dan hemat bahan bakar. Harga adalah sejumlah nilai yang diberikan oleh pelanggan untuk mendapatkan keuntungan dari memiliki atau menggunakan suatu produk baik barang maupun jasa (Engel et all,1994 ; Belch dan Belch, 2009). Setiap individu memberikan penilaian yang tidak sama pada harga suatu barang, karena dipengaruhi persepsi, kondisi dan lingkungan yang 
bersangkutan (Kotler, 2007; Tjiptono, 2009). Lumbantoruan et all (2016) dalam penelitiannya menggunakan indikator harga, antara lain keterjangkawan harga oleh konsumen, kesesuaian harga dengan kualitas dan harga bersaing dengan produk lain. Promosi merupakan kegiatan-kegiatan yang aktif dilakukan oleh perusahaan untuk mendorong konsumen membeli produk yang ditawarkan. Dalam promosi dikenal bauran promosi (promotion mix) yang terdiri dari 5 unsur utama yaitu; pengiklanan, penjualan pribadi (personal selling), hubungan masyarakat dan publisitas. pemasaran langsung (direct market) dan promosi penjualan (Zeithalm dan Marry, 2008; Kotler, 2007).

Meiliani dan Augusty (2015), dalam penelitiannya menggunakan indikator promosi, antara lain keunikan kegiatan promosi, atribut promosi yang menarik dan promosi provokatif. Perbandingan harapan atau ekspektasi pelanggan dengan yang diperoleh dari suatu perusahaan merupakan inti kualitas pelayanan (Munhurrun et all, 2014; Lukuhati et all, 2018; Wiratini et all, 2018). Kuliatas pelayanan dapat dibedakan menjadi lima kategori yaitu keandalan, daya tanggap, keyakinan, jaminan, empati dan yang berberwujud (Zeithalm dan Marry ,2008; Tjiptono, 2009; Nagara et all, 2020). Tunutan akan kualitas pelayanan sangat dinamis dari waktu ke waktu sesuai dengan lingkungan dan perusahaan berupaya memberikan pelayanan lebih dari harapan konsumen (Tjiptono, 2009 ; Nagara et all, 2020).

Kepuasan adalah perasaan senang atau kecewa setelah membeli dan menggunakan suatu produk (Engel et all,1994). Rasa senang atau kecewa tersebut mencul setelah konsumen membandingkan produk yang telah dibeli dengan produk lain. Jika konsumen puas, biasnya akan menjadi pelanggan loyal. (Setiadi, 2003; Winardi. 2005; Kotler, 2007). Pada umumnya konsumen mengharapkan kepuasan lebih besar atau paling tidak sama dengan barang yang telah pernah dipakai atau dipikirkan sebelumnya (Engel et all,1994; Grewal, 2004; Kotler dan Keller, 2009). Keputusan membeli dapat diartikan sebagai tindakan seseorang konsumen untuk melakukan pembelian setelah membandingkan dengan beberapa alternatif produk atau jasa lainnya (Engel et all, 1994 ; Kotler dan Keller, 2009). Sebelum melakukan pembelian, pada umumnya konsumen mencari informasi yang lengkap tentang produk yang akan dibeli dan produk alternatifnya (Engel et all, 1994; Ajzen dan Fishbei, 1980, Kotler, 2007),

\section{METODE PENELITIAN}

Populasi penelitian adalah konsumen yang membeli alat mesin pengolah kopi pada konsumen PT. Karya Mitra Usaha, Sampel atau responden ditentukan dengan metode purposive sampling dan accidental sampling. Purposive sampling dengan pertimbangan konsumen yang dijadikan responden target minimal telah membeli mesin pengolah kopi sebanyak dua kali, tujuannya untuk mengurangi bias dalam menjawab pertanyaan. Sedangkan Accidental sampling berkaitan dengan kesediaan responden dengan sukarela menjawab pertanyaan (Sugiyono, 2012). Jumlah responden sebanyak 79 orang.

Penelitian menggunakan 6 variabel dan setiap variabel direpresentasikan oleh beberapa indikator sebagai berikut; variabel pertama adalah kualitas produksi (X1) ditujukkan oleh indikator keandalan produk (X1.1), rancang bangun atau desain (X1.2), daya tahan (X1.3), hemat bahan bakar (X1.4), kemudahan dalam pengoperasian (X1.5), dan kemudahan perawatan (X1.6). Variabel kedua adalah harga (X2), diwakili oleh indikator keterjangkauan harga (X2.1), kesesuaian harga dengan manfaat produk (X2.2), Kesesuaian harga dengan kualitas produksi (X2.3), Daya saing harga dengan prosuk lain (X2.4). Variabel ketiga adalah Promosi (X3) yang direpresentasikan oleh indikator mengundang konsumen ke bengkel (workshop) pembuatan alat mesin pengolah kopi (X3.1), aktivitas kontak langsung dengan konsumen atau pelanggan (X3.2), menggunaan atau melalui online internet (X3.3), dan mengikutkan/mengundang pelanggan dalam kegiatan pameran (X3.4). Variabel keempat adalah kualitas pelayanan (X4) yang direpresentasikan oleh indikator kehandalan (X4.1), daya tanggap (X4.2),
Satisfaction and Marketing Mix 
Customer

Satisfaction and

Marketing Mix

dan empati (X4.3). Variabel kelima adalah kepuasan konsumen (Y1) yang direpresentasikan oleh indikator Selalu ada perbaikan kualitas produk (Y1.1), discount harga selalu diberitahukan (Y1.2), pelayanan dilakukan secara terus menerus (Y1.3), dan pelayanan purna jual (Y1.4). Variabel keenam adalah keputusan pembelian (Y2) yang direpresentasikan oleh indikator keinginan untuk segera membeli (Y2.1), keinginan untuk mencoba produk (Y2.2), keinginan memberitahukan pada rekan bisnis (Y2.3), keinginan mempengaruhi asosiasi membeli produk (Y2.4), dan menyarankan agar perusahaan memproduksi lebih sebagai persediaan (Y2.5).

Analisas data dilakukan dengan menggunakan persamaan regresi berganda sedangkan pengolahan data dengan bantuan SPSS (Ghozali, 2013). Model persamaan regresi terdiri dari dua struktur, sebagai berikut:

Model struktur I.

$\mathrm{Y} 1=\alpha \mathrm{o}+\alpha 1 \mathrm{X} 1+\alpha 2 \mathrm{X} 2+\alpha 3 \mathrm{X} 3+\alpha 4 \mathrm{X} 4+\varepsilon \mathrm{i}$

Model struktur II.

$\mathrm{Y} 2=\beta \mathrm{o}+\beta 1 \mathrm{X} 1+\beta 2 \mathrm{X} 2+\beta 3 \mathrm{X} 3+\beta 4 \mathrm{X} 4+\beta 5 \mathrm{Y} 1+\varepsilon \mathrm{i}$

dimana: $\alpha$ o dan $\beta$ o konstanta regresi, $\mathrm{X} 1$ kualitas produk, $\mathrm{X} 2$ harga, $\mathrm{X} 3$ promosi, $\mathrm{X} 4$ kualitas pelayanan, Y1 kepuasan konsumen, Y2 keputusan pembelian dan Ei kesalahan Hipotesis uji :

H1. Ada pengaruh langsung dan signifikan dengan arah positif dari masing-masing kualitas produksi, harga, promosi, pelayanan terhadap kepuasan konsumen dan terhadap keputusan membeli. Semakin tinggi kualitas produksi, promosi, pelayanan akan semakin tinggi kepuasan konsumen dan keputusan membeli.

H2. Ada pengaruh langsung dan signifikan dengan arah negatif dari harga terhadap kepuasan konsumen dan terhadap keputusan membeli. Semakin tinggi harga akan semakin rendah kepuasan konsumen dan keputusan pembelian dan sebaliknya

H3. Ada pengaruh simultan dan signifikan dengan arah positip dari kepuasan konsumen terhadap keputusan pembelian. Semakin tinggi kepuasan konsumen akan semakin tinggi juga keputusan membeli.

H4. Ada pengaruh pengaruh simultan dan bersifat signifikan dari kualitas produksi, harga, promosi dan pelayanan terhadap kepuasan konsumen.

H5. Ada pengaruh simultan dan bersifat signifikan dari kualitas produksi, harga, promosi, pelayanan dan kepuasan konsumen terhadap keputusan konsumen.

\section{HASIL DAN PEMBAHASAN \\ Uji Kualitas Data}

Hasil uji validitas dan reabilitas terpenuhi dalam pengujian dafar pertanyaan yang disusun dalam kuesioner. Demikian juga halnya dengan syarat kecukupan asumsi klasik, yaitu normalitas, mutikolinieritas dan juga hetroskedastisitas juga terpenuhi.

\section{Analisis Asosiasi Antar Variabel}

Pengaruh langsung dari masing-masing kualitas produksi, harga, promosi dan pelayanan baik terhadap kepuasan konsumen maupun terhadap keputusan pembelian dapat ditentukan berdasarkan persamaan struktur I dan II. Persamaan struktur I diperoleh dari hasil output SPSS (tabel 2) sebagai berikut: $\mathrm{Y} 1=3,759+0,643 \mathrm{X} 1$ $0,334 \mathrm{X} 2+0,279 \mathrm{X} 3+0,131 \mathrm{X} 4$. Sedangkan persamaam struktur II juga diperoleh dari output SPSS (tabel 3) sebagai berikut: Y2 $=7,279+0.463 \mathrm{X} 1-0,116 \mathrm{X} 2+0.211 \mathrm{X} 3$ $+0,105 \mathrm{X} 4+0,519 \mathrm{Y} 1+\mathrm{Ei}$.

Hipotesis pertama $(\mathrm{H} 1)$ adalah semakin tinggi kualitas produksi, promosi, pelayanan akan semakin tinggi kepuasan konsumen dan keputusan membeli.

\section{1) Pengaruh Langsung Kualitas produksi}

Hasil analisis data, diperoleh nilai $t$ hit $(6,670>\mathrm{t}$ tabel $(1,676)$ dan nilai sig $\alpha(0,000$ $<0,05$ ) dengan demikian Ho ditolak dan H1 diterima. Berdasarkan kedua kriteria penerimaan hipotesis tersebut dapat disimpulkan bahwa kualitas produksi berpengaruh langsung dan signifikan terhadap kepuasan konsumen mesin pengolah kopi dengan 
koefisien bernilai positip sebesar 0,643. Makna angka bernilai positip adalah semakin tinggi kualitas produksi mesin pengolah kopi yang dihasilkan perusahaan akan semakin tinggi kepuasan konsumen. Hal ini dapat diterima dengan mudah, kerena pada umumnya konsumen pengolah kopi mau membeli mesin pengolah yang berkualitas baik. Pengaruh kualitas sangat penting dalam bisnis yang mengandalkan kekuatan produksi dalam persaingan (Heizer dan Render, 2015). Berdasarkan hasil deskripsi jawaban responden sebesar $91 \%$ mengatakan sangat puas dengan daya tahan, $87 \%$ mengatakan sangat puas dengan kemudahan dalam perawatan, dan $86 \%$ menjawab sangat puas karena hemat bahan bakar.

Kemudian diperleh pula nilai $t$ hit $(3.522)>t$ tabel $(1,676)$ dan nilai sig $\alpha(0,000)<$ $5 \%$ atau Ho ditolak dan $\mathrm{H} 1$ diterima, jadi kualitas produksi berpengaruh langsung dan signifikan terhadap keputusan pembelian dengan koefisien bertanda positip sebesar 0,463 . Besaran koefisien positip bermakna semakin tinggi kualitas produksi akan semakin besar pula keputusan pembelian mesin tersebut. Hasil yang diperoleh dari penelitian ini sejalan dengan yang diperoleh peneliti lain, yang menemukan kualitas produksi berpengaruh langsung dan signifikan dengan arah positip terhadap keputusan konsumen. (Mahendra, 2014; Kristian dan Widyanti, 2016; Lumbantoruan et all, 2017; Sastrawati dan Rahyuda, 2017; Yogatama et all, 2019).

\section{2) Pengaruh Langsung Promosi}

Nilai thit $(440)>$ nilai $t(1,676)$ dan $\alpha$ sig $(0.001)<0,05$ (tabel 2). Hal ini berarti H0 ditolak H1 diterima atau kegitan promosi yang dilakukan perusahaan berpengaruh lansung dan signifikan terhadap kepuasan konsumen dengan koefisien arah bernilai positip sebesar 0,279. Apabila ada upaya promosi yang lebih baik akan meningkatkan kepuasan konsumen. Pada umumnya kegiatan promosi akan berpengaruh positip terhadap kepuasan konsumen (Kotler dan Keller, 2009 ; Sukirno et all, 2017). Dari jawaban responden diketahui bahwa 93\% responden sangat puas dengan adanya promosi dengan cara mengundang ke bengkel (workshop) perusahaan, sebesar $91 \%$ mengatakan sangat puas dengan mengikutkan pada kegiatan pameran dan 89\% mengatakan sangat puas dengan adanya kontak langsung secara berkesinambungan.

Diperoleh nilai t hit $(2.481)>t$ tabel $(1,676)$ dan nilai $\alpha$ sig $(0.001)<0,05$ dan hipotesis $\mathrm{H} 1$ diterima. Jadi promosi berpengaruh positip terhadap keputusan membeli dengan koefisien arah bernilai positip sebesar 0.211. Apabila ada upaya promosi yang lebih baik akan meningkatkan keputusan membeli. Hasil yang diperoleh dari penelitian ini sejalan dengan yang diperoleh peneliti lain, yang menemukan kegiatan promosi berpengaruh signifikan dengan arah positip terhadap keputusan konsumen (Setyorini, 2012; Meiliani dan Augusty, 2015; Hardandy dan Sri. 2015; Aina, 2017)

\section{3) Pengaruh Langsung Kualitas Pelayanan}

Nilai t hitung sebesar $0.112<\mathrm{t}$ tabel sebesar 1,676, dan nilai $\alpha$ sig $0.167>0,05$ (tabel 2), dengan demikian H0 diterma dan H1 ditolak. Berdasarkan kedua kriteria ini pelayanan yang diberikan perusahaan tidak signifikan pengaruh langsungnya terhadap kepuasan konsumen. Meskipun tidak signifikan, tetapi arahnya positip sebesar 0.131, hal ini berarti upaya perbaikan dalam kualitas pelayanan akan meningkatkan kepuasan konsumen. Hasil yang diperoleh dari penelitian ini agak berbeda dengan hasil yang ditemukan peneliti lain dalam bidang usaha jasa. Pada usaha jasa Café yang mejual beraneka ragam produk kopi menunjukan kualitas pelayanan berpengaruh langsung dan signifikan terhadap kepuasan konsumen dengan arah positip (Negara et all, 2020). Demikian juga halnya dengan penelitian yang dilakukan oleh Indrajaya (2018), menemukan pengaruh langsung dan signifikan serta bersifat positip antara kualitas pelayanan dengan kepuasan konsumen pada Galery UKM. Pada usaha jasa, yaitu bisnis pariwisata, banyak peneliti yang menemukan pengaruh kualitas peluyanan berpengaruh signifikan terhadap tungkat kepuasan wisatawan (Normasari et all, 2013; Marpaung, 2020). Nilai t hit $(0.557)<\mathrm{t}$ tabel $(1,676)$ dan $\alpha$ sig $0,117>0,05$ (tabel 3) atau Ho diterima dan $\mathrm{H} 1$ ditolak. Kualitas pelayanan yang diberikan perusahaan tidak signifikan pengaruhnya langsungnya terhadap keputusan membeli konsumen. Walaupun
Satisfaction and Marketing Mix 
Customer

Satisfaction and

Marketing Mix

tidak signifikan tetapi koefisien arahnya positip sebesar 0,105 , hal ini berarti upaya perbaikan dalam kualitas pelayanan akan meningkatkan keputusan pembelian. Tidak signifikannya pengaruh langsung kualitas pelayanan terhadap keputusan pembelian mungkin saja konsumen atau pembeli mesin pengolah kopi, tidak terlalu tertarik dengan pelayanan dan mungkin lebih tertarik pada kualitas produk, harga dan promosi dibandingkan dengan kualitas pelayanan yang diberikan perusahaan. Berdasarkan jawaban responden diketahu bahwa $63 \%$ responden sangat puas dengan keandalan staf perusahaan, sebesar $61 \%$ mengatakan sangat puas dengan daya tanggap staf atau tenaga dalam memberikan pelayanan dan $66 \%$ mengatakan sangat puas dengan empati yang diberikan oleh staf perusahaan.

\section{4) Pengaruh Langsung Harga}

Hipotesis kedua $(\mathrm{H} 2)$ adalah semakin rendah harga akan semakin tinggi kepuasan konsumen dan keputusan membeli dengan arah bersifat negatif. Nilai t hitung $(7,006)>$ nilai t tabel $((0,05 ; 75)$ dan nilai sig $\alpha<5 \%$ (tabel 2). Berdasarkan kedua kriteria tersbut, hipotesis Ho ditolak atau $\mathrm{H} 2$ diterima, atau dapat disimpulkan bahwa harga berpengaruh langsung dan signifikan dengan hubungan koefisien negatif sebesar 0,334 terhadap kepuasan konsumen. Angka negatif ini menunjukan berlakunya hukum permintaan, yaitu semakin tinggi harga semakin sedikit yang membeli dan sebaliknya, semakin murah harga semakin banyak yang beli. (Raharja dan Mandala, 2008; Sukirno et all, 2017). Dapat juga dikatakan semakin rendah harga mesin pengolah kopi akan semakin tinggi tingkat kepuasan konsumen dan sebaliknya semakin tinggi harga akan semakin rendah tingkat kepuasan konsumen. Hal ini dapat dipahami dengan mudah, karena pada umumnya konsumen menggunakan harga sebagai salah satu pertimbangan untuk menentukan tingkat kepuasan.

Diperoleh t hitung $(2.026)>$ nilai tabel $(1,676)$ dan sig $\alpha(0,000)<5 \%$ atau diterima Ho ditolak dan $\mathrm{H} 2$ diterima, maknanya adalah harga berpengaruh langsung dan signifikan terhadap keputusan pembelian konsumen dengan hubungan negatif sebesar 0.116 . Hasil yang diperoleh dari penelitian ini sejalan dengan yang diperoleh oleh peneliti lain (Mahendra, 2014; Putranto et all, 2015; Kristian dan Widyanti, 2016; Lumbantoruan et all, 2017; Pradana, 2017; Edy et all, 2019) yang menemukan harga berpengaruh signifikan dengan arah negatif terhadap keputusan pembelian. Hasil rekpitulasi jawaban responden menunjukkan bahwa $81 \%$ responden mengatakan harga produk yang ditawarkan perusahaan sangat terjangkau, sebanyak $79 \%$ mengatakan harga produk mesin pengolah kopi sesuai dengan manfaat yang mereka harapkan dan $86 \%$ mengatakan harga mesin pengolah kopi yang ditawarkan PT. Karya Mitra Usaha dapat bersaing dengan produk sejenis yang ditawarkan perusahaan lain.

\section{5) Pengaruh Langsung Kepuasan Konsumen Terhadap Keputusan Membeli}

Hipotesis ketiga $(\mathrm{H} 3)$ adalah semakin tinggi tingkat kepuasan akan semakin tinggi pula keputusan pembelian dengan arah bersifat positif. Kepuasan konsumen pengaruhnya langsung dan signifikan terhadap keputusan pembelian dengan arah positip sebesar 0,519 . Hal ini ditunjukkan nilai $t$ hit $(2.984)>t$ tabel $(1,676)$ dan nilai $\alpha$ sig 0.004>0,05 (tabel 3) dengan demikian Ho ditolak dan H3 diterima. Koefisien arah positip sebesar 0,519 bermakna bahwa semakin tinggi tingkat kepuasan konsumen akan semakin tinggi juga tingkat keputusan pembelian, dan sebaliknya semakin rendah tingkat kepuasan konsumen akan semakin rendah pula tingkat keputusan pembelian. Hasil penelitian ini sejalan dengan yang ditemukan oleh peneliti lain, yaitu kepuasan konsumen berpengaruh langsung dan signifikan dengan hubungan positip (Normasari et all, 2013; Munhurrun; 2014; Wiratini et all, 2018). Berdasarkan hasil deskripsi dari jawaban responden sebanyak $61 \%$ responen memgatakan sangat puas terhadap peruhaan, sebesar $27 \%$ mengatakan puas, $7 \%$ menjawab netral, $3 \%$ mengatakan tidak puas dan sisanya sebesar $2 \%$ mengatakan sangat tidak puas.

\section{6) Pengaruh Simultan terhadap Kepuasan Konsumen}

Hipotesis keempat (H4), yakni terdapat pengaruh simultan dan bersifat signifikan dari kualitas produksi, harga, promosi dan pelayanan terhadap kepuasan konsumen. Nilai 
anova (Anayisis of Varian) model struktur I dari output SPSS, nila F hit $(13,962)>$ $\mathrm{F}(5 \% ; 4 ; 74)$ sebesar 4,08 dan $\alpha$ sig $(000)<0,05$ (tabel 4), sehingga terima $\mathrm{H} 4$ dan tolak H0. Hasil uji ini menunjukkan signifikan pengaruh bersama-sama dari kempat faktor kualitas produksi, harga, promosi dan kualitas pelayanan terhadap kepuasan konsumen. Apabila disimak lebih jauh, hasil uji parsial (langsung) yang telah dijelaskan di depan, dimana pengaruh kualitas pelayanan tidak signifikan terhadap kepuasan konsumen, tetapi berdasarkan hasil uji simultan ternyata pengaruh kualitas pelayanan bersamasama dengan kualitas produksi, harga dan promosi menjadi signifikan pengaruhnya terhadap kepuasan konsumen. Nilai koefisien determinasi atau R square struktur I sebesar 0,625 atau 62,5\% (tabel 5) yang bermakna hanya sebesar 62,5\% keragaman (varian) variabel kepuasan konsumen sebagai variabel independen dapat dijelaskan oleh keempat variabel dependen (kualitas produksi, harga, kegiatan promosi dan kualitas pelayanan), sedangkan sisanya sebesar $37,5 \%$ tidak dapat dijelaskan keempat variabel bebas tersebut dan merupakan kesalahan atau Ei sebesar 37,5\%. Untuk meningkatkan koefisien determinasi tersebut, maka dalam penelitan selanjutnya perlu ditambah variabel bebas.

\section{7) Pengaruh Simultan terhadap Keputusan Pembelian}

Hipotesis kelima (H5), yaitu ada pengaruh simultan dari kualitas produksi, harga, promosi, pelayanan dan kepuasan konsumen terhadap keputusan pembelian. Nilai anova struktur 2 dari output SPSS disajikan pada tabel 6. Hasil uji ini menunjukkan signifikan pengaruh bersama-sama dari kelima variabel independen, yaitu kualitas produksi, harga, promosi, pelayanan dan kepuasan konsumen terhadap keputusan membeli (variabel dependen). Hal tersebut ditunjukkan oleh nilai F hit (4.561) $>\mathrm{F}$ tabel $(4,08)$ dan nilai peluang sig $(001)<0,05$, sehingga terima $\mathrm{H} 5$ dan tolak Ho.

Hal yang menarik disimak lebih jauh, hasil uji parsial (langsung) yang telah dijelaskan di atas, dimana pengaruh kualitas pelayanan tidak signifikan pengaruhnya terhadap keputusan konsumen ternyata berdasarkan hasil uji simultan pengaruh kualitas pelayanan bersama-sama dengan kualitas produksi, harga, promosi dan kepuasan konsmen, pengaruhnya menjadi signifikan terhadap keputusan konsumen. Hasil output SPSS yang memuat nilai $\mathrm{R}$ square strukur II (kepuasan konsumen sebagai variabel eksogen atau dependen) diperlihatkan pada tabel 7. Jumlah varian variabel independen keputusan pembelian yang dapat dijelaskan variabel dependen kualitas produksi, harga, promosi, pelayanan dan kepuasan konsumen sebesar 0,719 atau 71,9\%. Tidak dapat dijelaskan model sebesar 29,1\%. Apabila dibandingkan dengan model struktur I, maka terjadi kenaikan dari $\mathrm{R}$ square dari $62,5 \%$ menjadi $71,9 \%$. Dengan demikian peranan kepuasan konsumen sebagai variabel antara penting untuk meningkatkan nilai koefisien determinasi terhadap keputusan pembelian.

\section{8) Dampak Variabel Interventing Kepuasan Konsumen}

Dalam ekonometrik peranan koefisien-koefisien yang ada dalam persamaan regresi berhubungan dengen konsep elastisitas. Elastisitas dapat dimaknai sebagai respons veriabel dependen akibat adanya perubahan satu-satuan dari variabel independen, semakin tinggi nilai koefisien-koefisien tersebut akan semakin besar perubahan yang akan terjadi pada variabel independen (Raharja dan Mandala, 2008). Koefisien persamaan struktur I dengan menghilangkan nilai rata-rata (koefisien $\alpha \mathrm{o}$ ) sehingga persamaannya menjadi $\mathrm{Y} 1=0,643 \mathrm{X} 1-0,334 \mathrm{X} 2+0,279 \mathrm{X} 3+0,131 \mathrm{X} 4$, dengan cara yang sama dengan menghilangkan nilai rata-rata (koefisien $\beta 0$ ) dari struktur II, persamaan menjadi Y2 $=0.463 \mathrm{X} 1-0,116 \mathrm{X} 2+0.211 \mathrm{X} 3+0,105 \mathrm{X} 4+0,519 \mathrm{Y} 1$. Jika koefisien-koefisien kedua struktur tersebut dibuat dalam satu diagram mampak seperti gambar 1.

Menurut Ghozali (2013), berdasarkan koefisien pada kedua lintasan atau jalur tersebut dapat dihitung dampak tidak langsung dan dampak total terhadap keputusan pembelian, hasilnya sebagaimana pada tabel 9.

\section{Customer \\ Satisfaction and Marketing Mix}


Customer

Satisfaction and

Marketing Mix

Gambar 1 Koefisien- koefisien persamaan struktur I dan II

Tabel 9. Koefisien Langsung, Tidak Langsung Dan Total Serta Nilai Peningkatannya

\begin{tabular}{cccccc}
\hline $\begin{array}{c}\text { Variabel } \\
\text { Bebas }\end{array}$ & $\begin{array}{c}\text { Koefisien Langsung (direct effect) } \\
\text { Y1 }\end{array}$ & $\begin{array}{c}\text { Koefisien Tidak } \\
\text { (Kepuasan) }\end{array}$ & $\begin{array}{c}\text { Kangsung (indirect } \\
\text { (Keputusan Membeli }\end{array}$ & $\begin{array}{c}\text { Koefisien total } \\
\text { (total effect) }\end{array}$ & Peningkatan \\
\hline X1 & 0,643 & 0,463 & 0,334 & 0,797 & 0,334 \\
X2 & 0,334 & 0,116 & 0,173 & 0,289 & 0,173 \\
X3 & 0,279 & 0,211 & 0,145 & 0,356 & 0,145 \\
X4 & 0,131 & 0,105 & 0,068 & 0,173 & 0,068 \\
Y2 & & 0,519 & & &
\end{tabular}

Dampak dapat diartikan sebagai perubahan dari kondisi awal dengan konsisi ahkhir akibat suatu aktivitas atau perlakukan (Sukirno et all, 2017). Kondisi awal adalah nilai koefisien-koefisien langsung yang diperoleh dari perlakuan kepuasan konsumen sebagai variabel dependen (eksogen) dan kondisi akhir adalah nilai koefisien-koefisien yang diperoleh dengan perlakuan kepuasan konsumen sebagai variabel independen (endogen) terhadap keputusan pembelian.

\section{PENUTUP}

\section{Kesimpulan}

Beberapa kesimpulan penelitian ini adalah sebagai berikut :

1. Kualitas produksi dan kegiatan promosi berpengaruh langsung dan signifikan degan hubungan positip terhadap kepuasan konsumen dan keputusan pembelian. Sedangkan kualitas pelayanan pengaruh langsungnya tidak signifikan, tetapi bersifat positif terhadap kepuasan konsumen dan keputusan pembelian.

2. Harga berpengaruh langsung dan signifikan dengan arah negatif terhadap kepuasan konsumen dan keputusan konsumen.

3. Kepuasan konsumen berpengaruh langsung dan signifikan dengan hubungan positif terhadap keputusan pembelian.

4. Kualitas produksi, harga, kegiatan promosi dan kepuasan konsumen secara simultan berpengaruh signifikan terhadap kepuasan konsumen.

5. Kualitas produksi, harga, kegiatan promosi, kualitas pelayanan dan kepuasan konsumen secara simultan berpengaruh signifikan terhadap keputusan pembelian.

6. Kepuasan konsumen sebagai variabel interventing berdampak pada peningkatan koefisien total melalui peningkatan koefisien tidak langsung

\section{DAFTAR PUSTAKA}

[1] Aina, N. 2017. Pengaruh Iklan dan Citra Merek terhadap Keputusan Pembelian Sepeda Motor Honda Beat di Kelurahan Mungirejo Kecamatan Sungai Pinang Samarinda. eJournal Administrasi Bisnis. Volume 5 (1): 182-192.

[2] Belch, G.E dan Belch, M.A. 2009. Advertising and Promotion: An Integrated Marketing Communication Perspective, 7th Edition. New York: McGraw Hill. 
[3] Bilhak. A dan Samuel. M. 2014. Pengembangan Agribisnis Kopi Dalam Kerangka Pembangunan Ekonomi Wilayah Di Kabupaten Aceh Tengah (Studi Kasus: Kabupaten Aceh Tengah). Jurnal Teknik PWK. Volume 3 (2): 254-261

[4] Dirjen Perkebunan, 2020. Produksi Kopi Menurut Provinsi di Indonesia, 20162020.

[5] Edy. D.L., Widyanti., Erwin. K. M. 2019. Peningkatan Produktivitas Petani Tanaman Kopi Pemanfaatan Teknologi Mesin Pengering Kopi Bahan Bakar Briket Sebagai Bahan Bakar Alternatif. Sarwahita : Jurnal Pengabdian Kepada Masyarakat. Volume 16 (2): 172-182

[6] Engel, J. F., Roger, D.B., dan Paul, W. D. (1994). Perilaku Konsumen (Terjemahan). Edisi 6. Jakarta. Bina Aksara.

[7] Fauziah, P. and Mulyana, M., 2018, November. Formulation of The Green Marketing Development Strategy for the Body Shop Botani Square Bogor. In International Conference On Accounting And Management Science 2018 (pp. 171-181).

[8] Hardandy, A,D dan Sri, R, T, A. 2015. Analisis pengaruh kualitas produk, persepsi harga dan promosi terhadap keputusan pembelian honda revo fit fI. Diponegoro Jurnal of Management. Volume 4 (1)

[9] Heizer, J., dan Render, B. 2015. Manajemen Operasi: Manajemen Keberlangsungan dan Rantai Pasokan (Terjemahan)s. Jakarta. Penerbit Salemba Empat.

[10] Indrajaya. D. 2018. Analisis Kualitas Pelayanan Terhadap Tingkat Kepuasan Konsumen Menggunakan Metode Importance Performance Analysis Dan Customer Satisfaction Index Pada Ukm Gallery. Jurnal IKRA-ITH Teknologi . Volume 2 (3): 1 - 6 .

[11] Kelik. V., Hengky., Daniel. K 2016. Perancangan Mesin Pengupas Dan Pemisah Kulit Buah Kopi Kering . JTM. Volume 5 (2):. 28-34

[12] Kotler, P dan Keller, K. L. 2009. Manajemen Pemasaran. Edisi 12. Jakarta. Erlangga

[13] Kristian, D dan Widyanti, R. 2016. Pengaruh Kualitas Produk dan Harga terhadap Keputusan Pembelian Sepeda Motor Honda pada Mahasiswa Universitas Kampus 1 Kristen Krida Wajana. Jurnal Ilmiah Manajemen Bisnis. Volume 16 (1): 45-48.

[14] Lumbantoruan, R., Fitri, N, A., Hanifah, B., Indri, P. 2017 Seberapa besar kualitas produk mempengaruhi keputusan pembelian sepeda motor Honda Beat. JIM UPB. Volume 7 (1): 113-119.

[15] Mahendra, S. 2014. Pengaruh kualitas produk dan harga terhadap kepuasan konsumen Honda Beat. Jurnal Ilmu Manajemen. Volume 2 (1):

[16] Marpaung, B. 2019. Pengaruh Daya Tarik, Kualitas Pelayanan, Fasilitas Dan Keselamatan Dengan Kepuasan Wisatawan Sebagai Variabel Intervening Terhadapminat Kunjungan Ulang Wisatawan. Mpu Procuratio : Jurnal Penelitian Manajemen. Volume 1 (2): 144-155.

[17] Meiliani, N dan Augusty, T, F. 2015. Analisis pengaruh daya tarik disain produk, daya tarik promosi, dan persepsi kualitas terhadap citra merek serta dampaknya terhadap minat pembelian konsumen. Diponegoro Journal of Management.. Volume 5 (1): 1-11.

[18] Mulyana, M., Mashadi, M. and Syahputri, A.W., 2020, May. Determinants of Millenial Consumer Purchasing Decisions in Bukalapak. In 2nd International Seminar on Business, Economics, Social Science and Technology (ISBEST 2019) (pp. 113115). Atlantis Press.

[19] Munhurrun, P. R., V, N. Seebaluck., and P. Naidoo. 2014. Examining the structural relationship image, perceived value, tourist satisfaction and loyalty: case of Mauritius. Procedia Social and Behavioral Sciences. 175 (2015) ; 252 -259.

[20] Nagara, N., Erlina, P., Akmal, S. 2020. Analisis Peningkatan Kualitas Pelayanan Dengan Metode Servqual Dan Triz (Studi Kasus Pada "Cafe XYZ). Juminten : 
Customer

Satisfaction and Marketing Mix

38

Jurnal Manajemen Industri dan Teknologi . Volume 1 (1): 76 - 86 . http://juminten.upnjatim.ac.id/index.php/juminten, No. 01

[21] Pradana, P., Syarifah, H., Rahmawati. 2017. Pengaruh Harga Kualitas produk dan Citra Merek Brand Image Terhadap Keputusan Pembelian Motor. KINERJA. Volume 14 (1): 16-23.

[22] Purba, J.H.V., Ratodi, M., Mulyana, M., Wahyoedi, S., Andriana, R., Shankar, K. and Nguyen, P.T., 2019. Prediction Model in Medical Science and Health Care. International Journal of Engineering and Advanced Technology, 8, pp.815-818.

[23] Purwanto. A. P., Kukuh. M., Sri. M. Y. 2015. Model Pemberdayaan Masyarakat melalui Pengolahan Kopi di Desa Mandiri Energi. Agrokreatif- Jurnal Ilmiah Pengabdian kepada Masyarakat. Volume 1 (1): 28 - 34.

[24] Raharja, P dan Mandala, M. 2008, Teori Ekonomi Makro: Suatu Pengantar, edisi empat, Lembaga Penerbitan Fakultas Ekonomi Universitas Indonesia.

[25] Sastrawati, A, R dan Rahyuda I, K. 2017. Brand image memediasi kualitas produk dan harga dengan keputusan pembelian smartphone apple Di kota Denpasar. EJurnal Manajemen. Volume 6 (6) : 3252 - 3282.

[26] Setiadi, Nugroho J, 2003. Prilaku Konsumen, Penerbit Prenada Media, Jakarta Timur.

[27] Sukirno, S; Wan, S, H; Danny, S; Charles, S; Kurniawan, S, 2017. Pengantar Bisnis, Jakarta: Penerbit Kencana.

[28] Tjiptono, Fandy. 2009, Strategi Pemasaran, edisi kedua, cetakan ketujuh, Penerbit : Andi Offset, Yogyakarta

[29] Yogatama. M. R., Sunarto. C., Rudiati. E.M. 2019. Kajian Kinerja Peralatan Jasa Alat dan Mesin Pertanian (UPJA) Kontribusi dalam Strategi Pengembangan Alat dan Mesin Pertanian (Studi Kasus UPJA di DIJ. Agritech. Volume 21 (4):. 145-148 